\title{
A Study on Prevalence of Microorganisms on Surface of Brinjal (Solanum melongena L.) Collected from Local Market Yards across Junagadh District, India
}

\author{
Kajal Girdharbhai Kothadiya*
}

College of Veterinary Science and Animal Husbandry, Anand Agricultural University, Anand 388110, Gujarat, India

*Corresponding author

\begin{tabular}{|l|}
\hline Ke y w o r d s \\
Microbial load, \\
Prevalence, Total \\
plate count (TPC), \\
Post-harvest \\
treatment and Food \\
spoilage
\end{tabular}

\section{Introduction}

India's diverse climate ensures availability of all varieties of fresh fruits and vegetables. It ranks second in fruits and vegetables production in the world, after China. (National Horticulture Database published by National Horticulture Board, during 2015-16,
Brinjal (Solanum melongena L.) is an important solanaceous crop of sub-tropics and tropics. The Brinjal is being grown extensively in India. All vegetables have been known to serve as vehicles of human disease for at least a century. Vegetables can become contaminated with microorganisms capable of causing human diseases. This study was designed to determine the microbial load and prevalence of pathogens on surface of Brinjal in local market yards across Junagadh district. Brinjal samples were collected from the four talukas of Junagadh district (Visavadar, Mendarda, Vanthali and Junagadh) in two subsequent round and microbial load was assessed using different selective media for the growth of bacteria and fungi. Total plate count (CFU/gm) was highest in Mendarda local market yard samples which was $30 \times 10^{4} \mathrm{CFU} / \mathrm{gm}$ and lowest in Junagadh local market yard sample respectively. Yeast \& mold count on Brinjal was found up to $13 \times 10^{4}$ $\mathrm{CFU} / \mathrm{gm}$ for market yards of Junagadh district. Prevalence of E. Coli, Salmonella and Vibrio were observed in most of the samples collected form market yards could pose a health risk to consumers in the country. These high viable counts of microorganisms on Brinjal, could be because of unhygienic handling condition of local market, inappropriate transportation facility, improper storage condition etc. This can be reduce up to certain extent by giving suitable post-harvest treatment which can reduce food spoilage while maintaining sensory and nutritional characteristics of the fruits and vegetables. 
harvesting, transport, processing, distribution and marketing. Bacteria such as Clostridium botulinum, Listeria monocytogenes, Bacillus cereus etc. all are capable of causing illness and are normal inhabitants of soils, whereas Escherichia coli, Shigella, Salmonella, Campylobacter etc. reside in the intestinal tracts of humans and are more likely to contaminate vegetables through contact with sewage, feces, untreated irrigation water. Contamination may also occur during postharvest handling, including at points of preparation by street vendors, in food-service establishments and in the home (Cliver, 1997; Speer, 1997).

Brinjal or eggplant (Solanum melongena L.) is an important solanaceous crop of sub-tropics and tropics. The Brinjal is of much importance in the warm areas of Far East, being grown extensively in India, Bangladesh, Pakistan, China and the Philippines. It is also popular in Egypt, France, Italy and United States. India is considered to be the Centre of Origin of cultivated eggplant, from where it spread to the other parts of the world (Choudhury and Malda, 1968). In India it is the one of the most common and valuable vegetable (Sekara et al., 2007) and due to its wide usage in Indian foods it is described as "king of vegetables" (Choudhary and Gaur, 2009; Singh et al., 2014). It is primarily consumed as cooked vegetable in various ways and dried shoots are used as fuel in rural areas. It is low in calories and it contains mostly water, carbohydrate, protein, fibre, anthocyanin, phenols, glycoalkaloids etc. It is a good source of minerals and vitamins and is rich in reducing sugars, amide proteins among other nutrients (Bajaj et al., 1979; Kalra, et $a l .$, 1988). Brinjal is known to have ayurvedic medicinal properties and is good for diabetic patients. It has also been recommended as an excellent remedy for those suffering from liver complaints (Shukla and Naik, 1993). Raw and minimally processed vegetables like
Brinjals are an essential part of people's diet all around the world. Many advances in agronomic processing, practices, preservation, marketing and distribution have supported the raw vegetable industry to supply high-quality produce to many consumers all year round, some of these same practices have also expanded the geographical distribution and incidence of human illness associated with an increasing number of pathogenic bacterial, viral and parasitic microorganisms. Most of the contaminating flora is non pathogenic and has a natural occurrence on the produce. However, pathogens from the human and animal reservoir as well as other pathogens from environment can be found at the time of consumption. The survival of enteric pathogens in soil, manure, municipal wastes and irrigation water depends on different factors like relative humidity, microbial adhesion, rainfall, sunlight, etc. (De Rover, 1998). Exposure to non-pathogenic bacteria associated with plants may influence the development of allergies and the consumption of raw produce may represent an important means by which new lineages of commensal bacteria are introduced into the human gastrointestinal system (Hanski, 2012). The contamination of fruits and vegetables by bacteria could also be as a result of poor handling practices in food supply chain, storage conditions, distribution, marketing practices and transportation. Several studies have been carried out in many countries to determine the presence of pathogenic microorganisms on raw fruits and vegetables. In many instances, high percentages of samples have been found to contain microorganisms capable of causing human disease. To prevent contamination of vegetables during production, transport, processing and handling, much improvement is still needed if hygienic condition of vegetables is to be ensured. Furthermore, many microbial contaminants are part of the environment and vegetables may be 
inadvertently contaminated. The purpose of this work is to study the distribution and prevalence of microorganisms on the surface of Brinjal from the Junagadh district. It will help to design post-harvest treatment or surface decontamination treatment for the reduction of surface microbial flora from vegetable surface.

\section{Materials and Methods}

\section{Sample collection}

The Brinjal samples were collected from different local vegetable market yards of Junagadh district (Visavadar, Mendarda, Vanthali and Junagadh talukas). Three samples were collected twice at an interval of fifteen day's in sterile plastic bags from each market yard. After collections, samples were kept in proper container to transport from market yard to laboratory.

\section{Sample processing and isolation of microorganisms}

One grams of Brinjal surface was pilled from each of sample by sterilized knife and added to $9 \mathrm{ml}$ sterile distilled water to make $10^{-1}$ dilution. Then serial dilution upto $10^{-7}$ were carried out. $0.1 \mathrm{ml}$ from each dilution was spread on N-agar and Potato Dextrose agar plate for total bacterial and mould count respectively. $0.1 \mathrm{ml}$ from $10^{-1}$ dilution used for Eosin Methylene Blue and Vibrio agar media for E. coli and Vibrio spp. respectively. $1 \mathrm{ml}$ from $10^{-1}$ dilution was added to Fluid Selenite Cystine broth (FSC) for Salmonella enrichment and after $24 \mathrm{hrs}$. enriched FSC broth were transferred on Xylose Lysine Deoxycholate (XLD) agar for their selective isolation. These agar plates were incubated for $24 \mathrm{hrs}$ at $37^{\circ} \mathrm{C}$ for colony formation. Each colony was isolated in a pure form for further studies and identification by sub-culturing. Distinctive morphological properties of each pure culture such as colony form, elevation of colony and colony margin were observed. Microbial identification was done based on the method given by Jolt et al., (1994).

\section{Microbial load determination}

Bacterial quantification was done after $24 \mathrm{hrs}$ of incubation from nutrient agar plates. Whereas yeast and mold count was done after 3-4 days of incubation from potato dextrose agar plates. Plates with 30 to 300 colonies were selected for quantification. Total number of microorganisms was calculated by using following formula:

Total number of microorganisms $=$

Number of colony * Dilution factor

Volume plated

\section{Surface decontamination of Brinjal sample}

Surface decontamination of Brinjal sample was studied with water and neem leaf extracts wash. Collected Brinjal sample was dipped (for 5 minutes) and gently washed with water. Same way, Brinjal sample was dipped (for 5 minutes) and gently washes with Neem leaf water extracts. These washed samples were studied with control sample (unwashed sample) for Total plate count, Yeast and Mold count, E. coli, Vibrio and Salmonella spp.

\section{Results and Discussion}

Fruits and vegetables harbor a wide range of microbial contaminants as reported by Long et al (2002). The major bacterial populations that are generally present on fruits and vegetables include species of Pseudomonas spp., Bacillus spp., Enterobacter spp., Sarcina spp., Staphylococcus spp., Streptococcus spp., Lactobacillus spp. and Leuconostoc spp. as stressed by Erin (2010). Most of the 
vegetables were not really fresh as they stayed in the market for long periods resulting to their spoilage (Sahin et al., 1997). To evaluate microbial load of on Brinjal samples it was collected from four randomly selected market yards of Junagadh district at different time interval and analyzed for various parameters as below.

Total Plate Count

Yeast and Mold Count

Qualitative detection of E. coli

Qualitative detection of Salmonella spp.
Qualitative detection of Vibrio cholera.

Surface decontamination of Brinjal

\section{Total plate count of Brinjal}

Total plate count of Brinjal collected from Market yards of Junagadh District was in the range of $4 \times 10^{4}$ to $42 \times 10^{4} \mathrm{cfu} / \mathrm{gm}$ (Table 1 ). Out of the four market yard samples of Junagadh district, highest total plate count observed from Vanthali and lowest total plate count observed Junagadh market yard (Fig. $1)$.

Table.1 Microbial load of Brinjal samples collected from different market yard of junagadh district

\begin{tabular}{|c|c|c|c|c|c|c|}
\hline No & Place & $\begin{array}{c}\text { TPC Mean } \\
\text { Value }\left(\mathbf{X} \mathbf{1 0}^{\mathbf{4}}\right.\end{array}$ & $\begin{array}{c}\text { Y/M Mean } \\
\text { Value }\left(\mathbf{X} \mathbf{1 0}^{\mathbf{4}}\right.\end{array}$ & $\begin{array}{c}\text { E. coli } \\
(\mathbf{\%})\end{array}$ & $\begin{array}{c}\text { Salmonella } \\
(\mathbf{\%})\end{array}$ & $\begin{array}{c}\text { Vibrio } \\
(\mathbf{\%})\end{array}$ \\
\hline 1 & Visavadar & 15 & 3 & 17 & 83 & 50 \\
\hline 2 & Mendarada & 42 & 3 & 67 & 83 & 0 \\
\hline 3 & Vanthali & 10 & 1 & 50 & 0 & 33 \\
\hline 4 & Junagadh & 4 & 3 & 83 & 50 & 33 \\
\hline
\end{tabular}

Table.2 Microbial load of Brinjal sample treated with water and Neem leaf wash

\begin{tabular}{|l|l|c|c|c|c|c|}
\hline No & Sample & TPC & Y/M & E.coli & Salmonella & Vibrio \\
\hline $\mathbf{1}$ & Control & $12 \times 10^{4}$ & $154 \times 10^{2}$ & Present & Present & Present \\
\hline $\mathbf{2}$ & Water Wash & $6 \times 10^{4}$ & $12 \times 10^{2}$ & Present & Present & Present \\
\hline $\mathbf{3}$ & Neem Leaf Wash & $2 \times 10^{4}$ & $8 \times 10^{2}$ & Absent & Present & Present \\
\hline
\end{tabular}

Fig.1 Total plate count of Brinjal from different market yard of Junagadh district

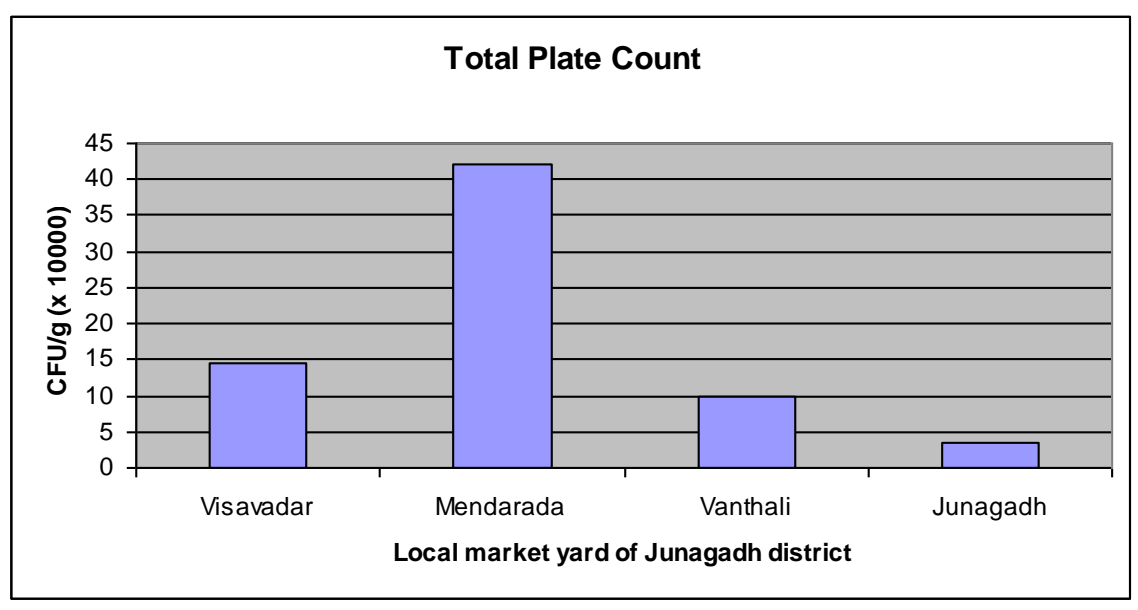


Fig.2 Yeast and Mold Count of Brinjal samples collected from different market yard of Junagadh district

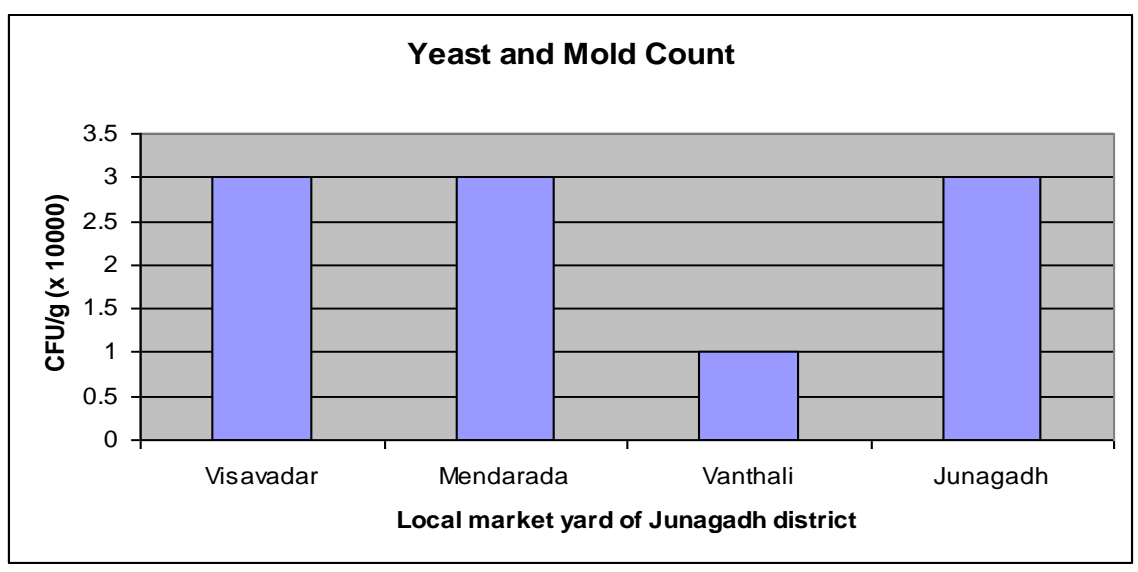

Fig.3 Presence of E. coli on Brinjal samples collected from different market yard of Junagadh district

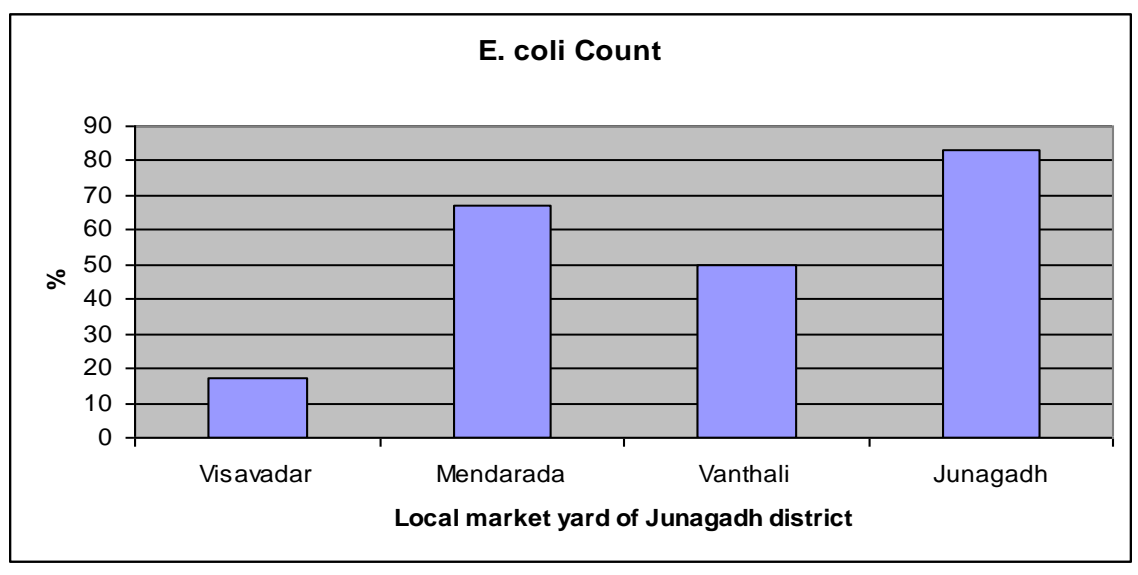

Fig.4 Presence of Salmonella spp. on Brinjal samples collected from different market yard of Junagadh district

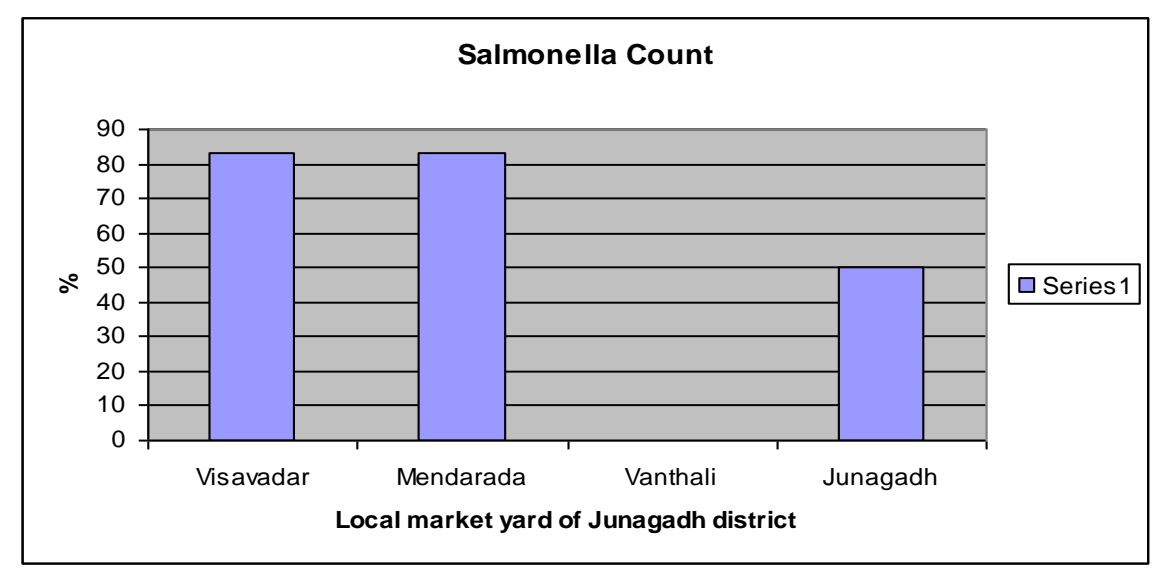


Fig.5 Presence of Vibrio spp. on Brinjal samples collected from different market yard of Junagadh district

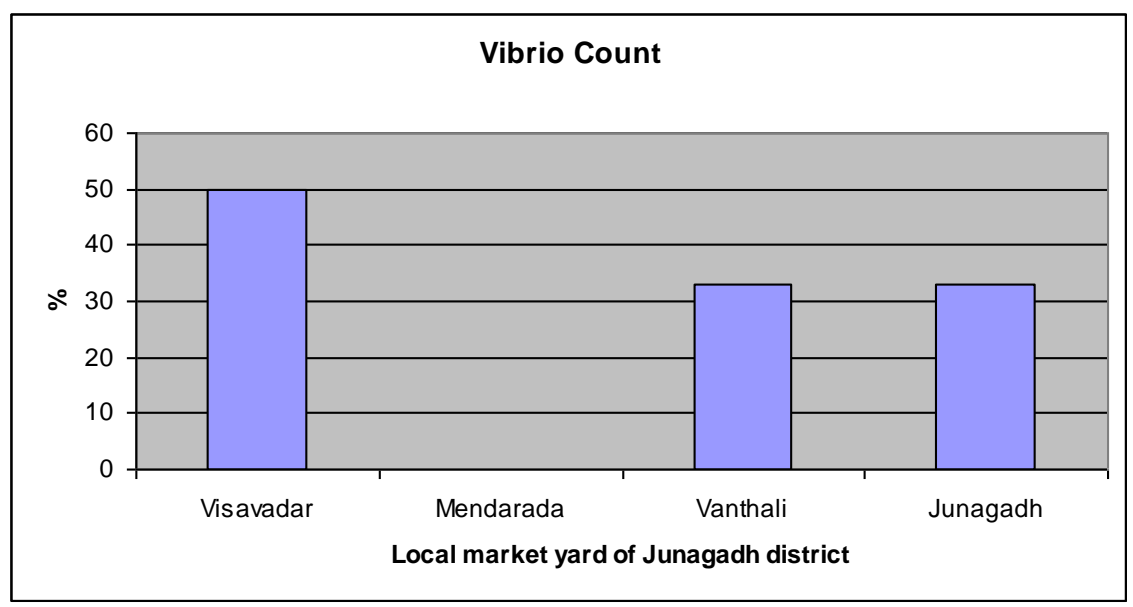

\section{Yeast and mold count of brinjal}

Yeast and Mold count of Brinjal collected from Market yards of Junagadh District was in the range of $1 \times 10^{4}$ to $3 \times 10^{4} \mathrm{cfu} / \mathrm{gm}$ (Table 1 and 2). Out of the four market yard samples of Junagadh district, Visavadar, Mendarada and Junagadh Market yard has Yeast and Mold count was around $3 \times 10^{4}$ $\mathrm{cfu} / \mathrm{gm}$. Vanthali was found with the lowest Yeast and Mold count which was around $1 \mathrm{x}$ $10^{4} \mathrm{cfu} / \mathrm{gm}$ (Fig. 2).

\section{Qualitative detection of $E$. coli}

E. coli $\%$ of Brinjal samples collected from different market yard of Junagadh district was observed in the range of $17-83 \%$ (Fig. 3). Out of the four market yard samples, Junagadh market yard showed highest presence of E.coli while samples collected from Visavadar market yard showed lowest contamination of E.coli.

\section{Qualitative detection of Salmonella spp.}

Salmonella spp. \% of Brinjal samples collected from different market yard of Junagadh district were observed in the range of $0-84 \%$ (Fig. 3). Out of the four market yard samples, Brinjal samples collected from the Visabadar and Mendarada market yard showed highest presence of Salmonella spp. however, it was not observed or absent in Vanthali market yard.

\section{Qualitative detection of Vibrio cholerae}

Vibrio cholerae \% of Brinjal samples collected from different market yard of Junagadh district were observed in the range of $0-50 \%$ (Fig. 3). Out of the four market yard samples, Brinjal samples collected from the Visabadar showed highest presence of Vibrio cholerae, however, it was not observed or absent in Mendarada market yard.

\section{Surface decontamination of brinjal sample}

Brinjal samples washed with water and Neem leaf extracts shows that the TPC, Y/M Count and E. Coli decrease gradually with water wash and neem water wash, while no changed occur in Vibrio Spp. and Salmonella typhi.

In conclusion, this comprehensive study was undertaken to detect the microbial load and prevalence of pathogens on Brinjal surface. The Brinjal samples were collected from four talukas of Junagadh distrct (Visavadar, 
Mendarda, Vanthali, Junagadh). These samples were studied for TPC, YMC and prevalence of E. coli, Salmonella typhi and Vibrio spp. Study shows that Brinjal samples collected from Local Market yard were harboring high microbial load with pathogenic microbial species. This could pose health risk to consumers. Source of microbial contamination of Brinjal samples may be from handling, source of water, local market yard, packaging, storage and transportation. In India majority of the people preferred to buy fresh vegetables from the Local Market. So, it is necessary to maintain good hygienic condition while handling, transport, storage, so risk of contaminants can be decreases and chances of food borne outbreaks can be minimized. Good hygienic condition can also be increased by pre-treatment of fresh produce by various anti-microbial agents to decrease the microbial load from the surface of the fresh produce.

\section{References}

Bajaj, K. L., Kaur, G., and Chadha, M. L. 1979. Glyco alkaloid content and other chemical constituents of the fruits of some eggplant (Solanum melongena L.) varieties. Journal of Plant Foods. 3(3): 163-168.

Choudhary, B., and Gaur, K. 2009. The development and regulations of $\mathrm{Bt}$ brinjal in India. ISAAA Brief, 38.Pp. 1- 2.

Choudhury, B., and Malada, T. S. 1968. Brinjal: A vegetable of masses. Indian Horticulture. 12: 21-22.

Cliver, D. O. 1997. Foodborne viruses In: Food Microbiology: Fundamentals and Frontiers (Eds.), M.P., Doyle, L.R., Beuchat and T. J., Montville. Washington, DC, American Society for Microbiology. Pp. 437-446.

De Rover, C. 1998. Microbial safety evaluations and recommendations on fresh produce. Food Control. 9(6): 321-347.

Erin, S. 2010. Influence of pre-harvest factor on postharvest quality. Biochemistry. 2: 133-145.

Hanski, I., Von Hertzen, L., Fyhrquist, N., Koskinen K., and Torppa, K. Laatikainen, T., Karisola, P., Auvinen, P., Paulin, L., Makela, M., Vartiainen, E., Kosunen, T., Alenius, H., Haahtela, T. 2012. Environmental biodiversity, human microbiota and allergy are interrelated. Proceedings of the National Academy of Sciences, USA, 109: 8334-8339.

Jolt, J. G., Krieg, N. R., Sneath, P. A., Stanley, J. T., and Williams, S. T. 1994. Bergey's manual of systematic bacteriology, $9^{\text {th }}$ edition. Williams and Wilkins Co. Baltimore, Maryland. Pp. 786.

Kalra, C. L., Berry, S. K., and Sehgal, R. C. 1988. A resume on brinjal (Solanum melongena L.), a most common vegetable. Indian Federation Packer. 42: 46-59.

Long, S. M., Adak, G.K. O'Brien, S. J., and Gillespie, I. A. 2002. General outbreaks of infectious intestinal disease linked with salad vegetables and fruit, England and Wales, 19922000. Communicable disease and public Health. 5: 101-105.

Sahin, F., and Miller, S. A. 1997. A source of resistance in Capsicum spp. accessions to pepper race 6 of Xanthomonas campestris pv. vesicatoria. Phytopathology. 87: S84-S84.

Sekara, A., Cebula, S., and Kunicki, E. 2007. Cultivated eggplants - origin, breeding objectives and genetic resources: A review. Folia Horticulturae, 19: 97-114.

Shukla, V., and Naik, L. B. 1993. Agro techniques of solanaceous vegetables, in 'Advances in Horticulture', Vol.5, 
Vegetable Crops, Part 1 (K. L. Chadha and G. Kalloo, eds.), Malhotra Pub. House, New Delhi. 365.

Singh, B. K., Singh, S., Singh, B. K., and Yadav, S. M. 2014. Some important plant pathogenic disease of Brinjal and their management. Plant Pathology Journal. 13 (3): 208-213.
Speer, C. A. 1997. Protozoan parasites acquired from food and water In: Food Microbiology: Fundamentals and Frontiers (Eds.), M.P., Doyle, L.R., Beuchat and T. J., Montville. Washington, DC, American Society for Microbiology. Pp. 478-493.

\section{How to cite this article:}

Kajal Girdharbhai Kothadiya. 2019. A Study on Prevalence of Microorganisms on Surface of Brinjal (Solanum melongena L.) Collected from Local Market Yards across Junagadh District, India. Int.J.Curr.Microbiol.App.Sci. 8(04): 2424-2431.

doi: https://doi.org/10.20546/ijcmas.2019.804.282 